\title{
Effect of Some Alternative Natural Compounds for Potato Sprout Control during Storage.
}

\author{
Shehata, S.A.*, and Manal M. Attia ** \\ * Faculty of Agriculture, Cairo University, Giza, Egypt \\ ** Postharvest and Handling of Vegetable Crops Department. Horticulture Research Institute. \\ Agriculture Research Center, Giza, Egypt.
}

\begin{abstract}
This study was carried out during two successive seasons of 2011/ 2012 and 2012/ 2013 on potato tubers of Desiree cultivar which harvested at fully mature stage to evaluate the performance of clove oil at the concentrations of 50,100 ppm and hydrogen peroxide $\left(\mathrm{H}_{2} \mathrm{O}_{2}\right)$ at $1 \%$ and $2 \%$ as a natural alternative to CIPC for control sprouting and maintaining quality in treated potato tubers kept at $10{ }^{\circ} \mathrm{C}$ and $85 \%$ RH for 5 months.

The results showed that sprouting percentage, sprout length, weight loss percentage and decay were increased with prolonging the storage period, while tuber starch\% was decreased with time of storage. All treatments retained tuber weight during storage as compared with the control (untreated) tubers. No sprouts and decay were observed with clove oil at $100 \mathrm{ppm}$ treatment in all storage period, while these characters started to be shown early after two months of storage with untreated tubers (control).

Clove oil at $50 \mathrm{ppm}$ and $\mathrm{H}_{2} \mathrm{O}_{2}$ at $1 \%$ were less effective in reducing weight loss $\%$, sprouts $\%$ and decay. Potato tubers treated with clove oil at $100 \mathrm{ppm}, \mathrm{H}_{2} \mathrm{O}_{2}$ at $2 \%$ and CIPC treatments were significantly higher in dry matter and starch content as compared with the other treatments.

The results suggest that potato tubers treated with Clove oil at $100 \mathrm{ppm}$ or $\mathrm{H}_{2} \mathrm{O}_{2}$ at $2 \%$ is a promising as natural alternative to CIPC for control sprouting and maintenance quality during storage at $10{ }^{\circ} \mathrm{C}$ for 5 months
\end{abstract}

Keywords: Potato, CIPC, Clove oil, Sprout, Storage

\section{Introduction}

Sprouting is a major of losses in stored potatoes not only does sprouting reduce the number of marketable potatoes, but intense evaporation of water from sprout surface also reduces the weight of the remaining tubers (Afek and Warshavsky. 1998), conversion of starch to sugars, which is undesirable in the processing industry due to darkening of fried products (Rastovski, 1987), visible sprouts on potatoes are unacceptable to consumers.

At harvest and for a finite period thereafter, potato tubers will not sprout and are considered as dormant (Burton, 1989). The length of this dormant period is dependent on the genotype as well as on both pre- and postharvest conditions (Okagami and Tanno,1992). Controlling the length of dormancy period could therefore be of considerable economic importance (Abd El-Moneim et al., 2012).

Alternative materials for sprout suppression are limited once the end of the dormancy period has been reached and potato is sprouting. There were two mean methods of keeping potatoes sprout free during storage. Storing at low temperature $\left(2-4{ }^{\circ} \mathrm{C}\right)$ and using sprouts suppressants (Prang, et al., 1997). Low temperatures can lengthen the marketing window by retarding sprout development, however, cause the degradation of starch to sugar and increase the tuber sweetness(Es and Hartmans, 1987b)which brings about an unfavorable browning of potato fries because of Maillard reactions during processing products to fry dark resulting in unacceptable product color (Taper- Bamnolker et al., 2010 ; Saravia and Rorogues, 2011).

Therefore, low temperature storage is not appropriate for potatoes designed for the processing market (Frazier et al., 2004). Many chemical compounds are known to inhibit sprouting. the sprout inhibitors chloropropham (CIPC) have proved to be of value (Buitelaar, 1987; yada et al.,1991)chloropropham(CIPC), is a commonly used postharvest sprout inhibitor. CIPC is applied to bulk potatoes in storage as an aerosol at rates of 17 to 22 ppm at $10-12^{\circ} \mathrm{C}($ Kleinkopf et al .,2003). However, their application can be problematic. Due to environmental concerns, in several countries use of CIPC and other chemicals are either restricted or may become restricted (Afek and Warshavsky, 1998).

Alternative sprout inhibitors of CIPC continue to be evaluated oils of some herbs and spicesessential oils have been shown to reduce sprouting in potatoes and can be applied to certified organic crops (Taper- Bamnolker et al., 2010). These compounds are volatile plant derivatives including peppermint oil and clove oil. Other compound such as hydrogen peroxide $\left(\mathrm{H}_{2} \mathrm{O}_{2}\right)$ is also have sprout suppression properties, $\mathrm{H}_{2} \mathrm{O}_{2}$ is also allowable by federal organic standards. 
Clove oil can be used effectively for potato sprout control but multiple applications at three week intervals will be required for long- term suppression (Frazier et al., 2006). The sprout suppressant properties of clove oil are ideal for an organic crop or a crop destined for export to a country that does not allow CIPC. Another use for this product may be to remove sprouts if a failure of traditional sprout control methods has occurred (Olsen et al., 2004). The active of ingredient of clove oil is eugenol and other eugenol - based components in the distillate produce (Abd El-Monem et al., 2012). Also, clove oil have been shown to inhibit growth of fusarium sambucinum on potato (Frazier et al., 2006) and sprouting of potato (Olsen et al., 2004), without degrading the color or quality of potato products (Frazier et al., 2006; El Sadr and Wateres 2005) reduced the incidence and severity of silver scurf on the surface of a tuber during storage when applied frequently (Olsen et al., 2004)

The application of hydrogen peroxide $\left(\mathrm{H}_{2} \mathrm{O}_{2}\right)$ to organic produce is allowed by the national organic program standards. $\mathrm{H} 2 \mathrm{O} 2$ have suppressed sprouting by physically damaging the developing sprouts or buds before they can elongate. $\mathrm{H}_{2} \mathrm{O}_{2}$ probably adversely affects merisematic tissue that is formed after the natural dormancy is lost in the tuber (Afek et al., 2000).

Repeated or continues application of many of these navel sprout suppressants will be necessary to achieve the long term sprout free conditions in storage (Kleinkopf et al., 2003). An added benefit from the use of several of these alternative materials is the effect on storage pathogens (Frazier et al., 2004). Clove oil and $\mathrm{H}_{2} \mathrm{O}_{2}$ have been shown to reduce pathogen of potatoes during storage (Frazier et al., 2004).

This comparative study evaluated the performance of clove oil and $\mathrm{H}_{2} \mathrm{O}_{2}$ as natural alternative to CIPC to control sprouting and maintenance quality in treated potato tubers kept at $10^{\circ} \mathrm{C}$ for 5 months.

\section{Materials and Methods}

Potato tubers (Solanum tuberosum 1. ) cv Desiree were harvested at fully mature stage from the farm of Faculty of Agriculture, Cairo Univ. at Giza Governorate, in the first and second week of November 2011 and 2012 seasons, respectively, then transferred to postharvest laboratory at Giza, sorted and cured for 10 days at $18^{\circ} \mathrm{C}$ and relative humidity $85 \%(\mathrm{RH})$. After curing, healthy uniform tubers $(40-60 \mathrm{~mm})$ were selected and exposed to the different treatments

1. CIPC at $50 \mathrm{ppm}$

2. Clove oil at $50 \mathrm{ppm}$

3. Clove oil at $100 \mathrm{ppm}$

4. Hydrogen peroxide $\left(\mathrm{H}_{2} \mathrm{O}_{2}\right)$ at $1 \%$
5. Hydrogen peroxide $\left(\mathrm{H}_{2} \mathrm{O}_{2}\right)$ at $2 \%$

6. Untreated (control)

All the previous treatments were applied with spray as fog over the tubers at $25{ }^{\circ} \mathrm{C}$ and $80 \% \mathrm{RH}$. Essential oil as clove oil was emulsified by tween 20 at dose $1 \mathrm{ml} / \mathrm{L}$. All the samples of potato tubers were packed in mesh bag and each had $2 \mathrm{~kg}$ (10- 12 tuber) represented as one replicate, fifteen replications were prepared for each treatment.

The samples were arranged in a complete randomized design and stored at $10{ }^{\circ} \mathrm{C}$ and $85 \%$ RH for 5 months. The treatments were repeated every one month interval during the storage term. Samples were taken at random in three replications and evaluated every one month intervals to determine:

1. Weight loss percentage,

2. Sprouting percentage by counting the number of sprouts. A tuber considered sprouted when it had at least one sprout of $2 \mathrm{~mm}$ length (Afek et al., 2000)

3. Sprout length $(\mathrm{cm})$.

4. Decay percentage.

5. Dry matter content .

6. Starch percentage measured according to Somogyi (1952) and Nelson (1974).

All data were subjected to the statistical analysis according to the method described by Senedecor and Cochran (1980).

\section{Results and Discussion}

\section{Weight loss percentage:}

Data in Table (1) show that weight loss percentage of potato tubers was increased considerably and consistently with the prolongation of storage period. The weight loss is natural consequence of catabolism of horticulture products, the loss in weight may be attributed to respiration and other senescence related metabolic processes during storage (Wills et al., 1981). Similar results were reported by Awad et al. (2007).

Concerning the effect of postharvest treatments on weight loss percentage, data reveal that there were significant differences between treatments in weight loss percentage during storage. However, all treatments retained their weight during storage as compared with the control (untreated) tubers.

Moreover, potato tubers exposed to CIPC, clove oil at $100 \mathrm{ppm}$ and hydrogen peroxide at $2 \%$ resulted in prominent reduction in weight loss percentage with non significant between them. Clove oil at 50 ppm and $\mathrm{H}_{2} \mathrm{O}_{2}$ at $1 \%$ were less effective in reducing the weight loss of tubers during storage. The highest value of weight loss percentage was recorded with untreated control. Similar results were obtained by (Owolabi et al.,2013) for clove oil and Afek, et al., (2000) for $\mathrm{H}_{2} \mathrm{O}_{2}$. The reduction of weight loss 
percentage by using clove oil or $\mathrm{H}_{2} \mathrm{O}_{2}$ may be attributed to reducing the respiration process rates and sprouting in potatoes during postharvest storage (Frazier et al., 2004).

As for the interaction between the used postharvest treatments and storage period, data in Table (1) show that potato tubers exposed to CIPC, clove oil at $100 \mathrm{ppm}$ and $\mathrm{H}_{2} \mathrm{O}_{2}$ at $2 \%$ had the lowest weight loss percentage during all storage period. These results were true in the two seasons.
The essential oil and basic components were found to act as an uncoupling agent in mitochondria at low concentration (pauly et al., 1981), thereby, inhibit mitochondrial respiration (Sharma,2012), membrane disturbances (Sharma,2012), which may be suppressing to the sprouting. Similar finding was obtained by (Frazier et al., 2004) who reported that clove oil and $\mathrm{H}_{2} \mathrm{O}_{2}$ treatments were the most effective treatments for reducing number of sprouts on potato tubers and preventing weight losses of tubers.

Table 1. Effect of sprout suppression on weight loss $\%$ of potato tubers during storage at $10{ }^{\circ} \mathrm{C}$.

\begin{tabular}{|c|c|c|c|c|c|c|c|}
\hline \multirow{3}{*}{ Treatments } & \multicolumn{6}{|c|}{ Storage periods(months) } & \multirow{3}{*}{ Mean } \\
\hline & 0 & 1 & 2 & 3 & 4 & 5 & \\
\hline & \multicolumn{6}{|c|}{$2011-2012$} & \\
\hline CIPC at 50 ppm & 0.00 & 0.32 & 1.25 & 2.17 & 3.12 & 4.02 & 1.81 \\
\hline Clove oil at $50 \mathrm{ppm}$ & 0.00 & 0.39 & 1.37 & 2.28 & 3.29 & 4.34 & 1.95 \\
\hline Clove oil at $100 \mathrm{ppm}$ & 0.00 & 0.28 & 1.13 & 2.08 & 3.02 & 3.80 & 1.72 \\
\hline $\mathrm{H}_{2} \mathrm{O}_{2}$ at $1 \%$ & 0.00 & 0.41 & 1.46 & 2.34 & 3.42 & 4.49 & 2.02 \\
\hline $\mathrm{H}_{2} \mathrm{O}_{2}$ at $2 \%$ & 0.00 & 0.32 & 1.03 & 2.11 & 3.18 & 3.91 & 1.76 \\
\hline Untreated (Control) & 0.00 & 0.45 & 1.46 & 2.85 & 3.92 & 5.26 & 2.32 \\
\hline Mean & 0.00 & 0.36 & 1.28 & 2.31 & 3.33 & 4.30 & 1.93 \\
\hline \multirow[t]{2}{*}{ L S D at 5\% } & $\mathrm{T}$ & 0.10 & $S$ & 0.13 & $\mathrm{~T} * \mathrm{~S}$ & 0.18 & \\
\hline & \multicolumn{7}{|c|}{$2012-2013$} \\
\hline CIPC at 50 ppm & 0.00 & 0.24 & 1.17 & 2.31 & 3.06 & 4.23 & 1.84 \\
\hline Clove oil at $50 \mathrm{ppm}$ & 0.00 & 0.31 & 1.28 & 2.42 & 3.19 & 4.52 & 1.95 \\
\hline Clove oil at $100 \mathrm{ppm}$ & 0.00 & 0.20 & 1.06 & 2.19 & 2.91 & 3.64 & 1.67 \\
\hline $\mathrm{H}_{2} \mathrm{O}_{2}$ at $1 \%$ & 0.00 & 0.33 & 1.38 & 2.46 & 3.65 & 4.62 & 2.07 \\
\hline $\mathrm{H}_{2} \mathrm{O}_{2}$ at $2 \%$ & 0.00 & 0.24 & 1.00 & 2.03 & 2.97 & 3.82 & 1.68 \\
\hline Untreated (Control) & 0.00 & 0.39 & 1.63 & 3.17 & 4.31 & 5.67 & 2.53 \\
\hline Mean & 0.00 & 0.25 & 1.25 & 2.43 & 3.35 & 4.42 & 1.95 \\
\hline L S D at $5 \%$ & $\mathrm{~T}$ & 0.14 & $\mathrm{~S}$ & 0.18 & $\mathrm{~T} * \mathrm{~S}$ & 0.21 & \\
\hline
\end{tabular}

\section{Sprouting percentage}

Data in Table (2) show that the percentage of sprouted tubers was increased thereafter but at different rates for the various storage treatments, all treatments delayed the appearance of sprouts, the most effective treatment against sprouting was CIPC and clove oil at $100 \mathrm{ppm}$ and $\mathrm{H}_{2} \mathrm{O}_{2}$ at $2 \%$ in the two seasons. No sprouts were observed with clove oil at $100 \mathrm{ppm}$ treatment until the end of storage period (5 months). Similar finding was obtained by (Frazier $\boldsymbol{e} t$ al., 2004) who reported that clove oil and $\mathrm{H}_{2} \mathrm{O}_{2}$ treatments were the most effective treatments for reducing number of sprouts, on potato tubers and preventing weight loss of tubers.

At the end of storage, statistical analysis showed that the differences were significant in both seasons. However untreated (control) tubers reached complete sprouting $(100 \%)$ in both seasons at 5 months of storage. On the other hand clove oil, at $50 \mathrm{ppm}$ and $\mathrm{H}_{2} \mathrm{O}_{2}$ showed 15.06 and 7.49 (average of the two seasons), respectively.

The effect of CIPC on inhibition of sprouting may be due to CIPC inhibits development by interfering with cell division through interrupting the spindle formation during active mitosis (Kleinkoph et al., 2003; Frazier et al., 2006). Cell division not only mandatory for sprout growth, but is also necessary to form the wound periderm during the wound- healing period in storage wound healing requires the production of three to ten cell layers resulting from cell division, consequently, CIPC must be applied after the wound-healing period is over, but before dormancy break or inhibition of sprout growth (Anangmous, 2001).

Clove oil does not have the efficacy on mode of action as CIPC, but it does have ideal sprout suppressant properties for organic potatoes, potatoes designed into non- CIPC allowed markets, or to temporarity remove or blacken sprout just prior to marketing (Olsen et al.,2004) .One benefit of using Clove oil for sprout control sprouts in storage is the ability to capitalize on the inherent dormancy of cultivar (Frazier et al., 2004).

Hydrogen peroxidase $(\mathrm{H} 2 \mathrm{O} 2)$ has suppressed sprouting by physically damaging the developing sprouts or buds before they can elongate. $\mathrm{H}_{2} \mathrm{O}_{2}$ probably adversely affects meristematic tissue is formed after the natural dormancy is lost in the tuber (Kleinkoph et al., 2003). A microscopic examination 
indicates that the action of $\mathrm{H}_{2} \mathrm{O}_{2}$ in inhibition of potato sprouting is by damaging the sprout tips (Afek et al., 2000). Also Abd- El Moneim et al. (2012) found that tubers dormancy and sprouting can be controlled in potato by the manipulation of $\mathrm{H}_{2} \mathrm{O}_{2}$ metabolism via the inhibition of catalase activity (CAT).The possible mechanisms whereby CAT inhibitors or $\mathrm{H}_{2} \mathrm{O}_{2}$ overcome dormancy and promote sprouting in potato tuber.

Table 2. Effect of sprout suppression on sprouting $\%$ of potato tubers during storage at $10{ }^{\circ} \mathrm{C}$.

\begin{tabular}{|c|c|c|c|c|c|c|c|}
\hline \multirow{3}{*}{ Treatments } & \multicolumn{6}{|c|}{ Storage periods(months) } & \multirow{3}{*}{ Mean } \\
\hline & 0 & 1 & 2 & 3 & 4 & 5 & \\
\hline & \multicolumn{6}{|c|}{$2011-2012$} & \\
\hline CIPC at 50 ppm & 0.00 & 0.00 & 0.00 & 0.00 & 0.00 & 9.42 & 1.57 \\
\hline Clove oil at $50 \mathrm{ppm}$ & 0.00 & 0.00 & 0.00 & 0.00 & 10.12 & 17.93 & 4.64 \\
\hline Clove oil at $100 \mathrm{ppm}$ & 0.00 & 0.00 & 0.00 & 0.00 & 0.00 & 0.00 & 0.00 \\
\hline $\mathrm{H}_{2} \mathrm{O}_{2}$ at $1 \%$ & 0.00 & 0.00 & 0.00 & 0.00 & 12.11 & 20.32 & 5.41 \\
\hline $\mathrm{H}_{2} \mathrm{O}_{2}$ at $2 \%$ & 0.00 & 0.00 & 0.00 & 0.00 & 0.00 & 8.73 & 1.46 \\
\hline Untreated (Control) & 0.00 & 0.00 & 10.42 & 35.18 & 77.20 & 100.00 & 37.13 \\
\hline Mean & 0.00 & 0.00 & 1.74 & 5.86 & 16.57 & 26.07 & 8.37 \\
\hline \multirow[t]{2}{*}{ L S D at $5 \%$} & $\mathrm{~T}$ & 1.12 & $\mathrm{~S}$ & 1.42 & $\mathrm{~T} * \mathrm{~S}$ & 1.54 & \\
\hline & \multicolumn{7}{|c|}{$2012-2013$} \\
\hline CIPC at 50 ppm & 0.00 & 0.00 & 0.00 & 0.00 & 0.00 & 11.27 & 1.88 \\
\hline Clove oil at 50 ppm & 0.00 & 0.00 & 0.00 & 0.00 & 8.14 & 12.18 & 3.39 \\
\hline Clove oil at $100 \mathrm{ppm}$ & 0.00 & 0.00 & 0.00 & 0.00 & 0.00 & 0.00 & 0.00 \\
\hline $\mathrm{H}_{2} \mathrm{O}_{2}$ at $1 \%$ & 0.00 & 0.00 & 0.00 & 0.00 & 6.19 & 22.55 & 4.79 \\
\hline $\mathrm{H}_{2} \mathrm{O}_{2}$ at $2 \%$ & 0.00 & 0.00 & 0.00 & 0.00 & 0.00 & 6.24 & 1.04 \\
\hline Untreated (Control) & 0.00 & 0.00 & 19.42 & 41.82 & 81.25 & 100.00 & 40.42 \\
\hline Mean & 0.00 & 0.00 & 3.24 & 6.97 & 15.93 & 25.37 & 8.58 \\
\hline L S D at $5 \%$ & $\mathrm{~T}$ & 1.21 & $\mathrm{~S}$ & 1.34 & $\mathrm{~T} * \mathrm{~S}$ & 1.62 & \\
\hline
\end{tabular}

\section{Sprout length}

Concerning the average sprout length, data in Table (3) show that the effect of different postharvest treatments as sprout suppression applied to potato tuber during storage. A tuber was considered sprouted when it had at least one sprout of $2 \mathrm{~mm}$ length (Afek et al., 2000). Sprout length of potato tubers increased considerably and consistently with prolongation of storage period. These results were agreement with those obtained by (Awad et al., 2007).

Table 3. Effect of sprout suppression on sprout length of potato tubers during storage at $10{ }^{\circ} \mathrm{C}$.

\begin{tabular}{|c|c|c|c|c|c|c|c|}
\hline \multirow{3}{*}{ Treatments } & \multicolumn{6}{|c|}{ Storage periods(months) } & \multirow{3}{*}{ Mean } \\
\hline & $\mathbf{0}$ & 1 & 2 & 3 & 4 & 5 & \\
\hline & \multicolumn{6}{|c|}{$2011-2012$} & \\
\hline CIPC at 50 ppm & 0.00 & 0.00 & 0.00 & 0.00 & 0.18 & 0.38 & 0.09 \\
\hline Clove oil at $50 \mathrm{ppm}$ & 0.00 & 0.00 & 0.00 & 0.00 & 0.41 & 0.82 & 2.05 \\
\hline Clove oil at $100 \mathrm{ppm}$ & 0.00 & 0.00 & 0.00 & 0.00 & 0.00 & 0.10 & 0.02 \\
\hline $\mathrm{H}_{2} \mathrm{O}_{2}$ at $1 \%$ & 0.00 & 0.00 & 0.00 & 0.00 & 0.51 & 1.06 & 0.26 \\
\hline $\mathrm{H}_{2} \mathrm{O}_{2}$ at $2 \%$ & 0.00 & 0.00 & 0.00 & 0.00 & 0.12 & 0.31 & 0.07 \\
\hline Untreated (Control) & 0.00 & 0.00 & 1.63 & 2.94 & 4.19 & 6.27 & 2.51 \\
\hline Mean & 0.00 & 0.00 & 0.27 & 0.49 & 0.90 & 0.00 & 0.83 \\
\hline \multirow[t]{2}{*}{ L S D at $5 \%$} & $\mathrm{~T}$ & 0.04 & $\mathrm{~S}$ & 0.07 & $\mathrm{~T} * \mathrm{~S}$ & 0.1 & \\
\hline & \multicolumn{7}{|c|}{$2012-2013$} \\
\hline CIPC at 50 ppm & 0.00 & 0.00 & 0.00 & 0.00 & 0.20 & 0.41 & 0.10 \\
\hline Clove oil at 50 ppm & 0.00 & 0.00 & 0.00 & 0.00 & 0.62 & 1.07 & 0.28 \\
\hline Clove oil at $100 \mathrm{ppm}$ & 0.00 & 0.00 & 0.00 & 0.00 & 0.00 & 0.18 & 0.03 \\
\hline $\mathrm{H}_{2} \mathrm{O}_{2}$ at $1 \%$ & 0.00 & 0.00 & 0.00 & 0.00 & 0.71 & 1.14 & 0.31 \\
\hline $\mathrm{H}_{2} \mathrm{O}_{2}$ at $2 \%$ & 0.00 & 0.00 & 0.00 & 0.00 & 0.17 & 0.36 & 0.09 \\
\hline Untreated (Control) & 0.00 & 0.00 & 1.25 & 2.34 & 3.94 & 5.11 & 2.11 \\
\hline Mean & 0.00 & 0.00 & 0.21 & 0.39 & 0.94 & 1.38 & 2.92 \\
\hline L S D at $5 \%$ & $\mathrm{~T}$ & 0.05 & $\mathrm{~S}$ & 0.08 & $\mathrm{~T} * \mathrm{~S}$ & 1.10 & \\
\hline
\end{tabular}


Concerning the effect of sprout suppression, data reveal that there were significant differences in sprout length between tubers in the control and treatment. Obviously all treatments did not show any sprout growth until 30 days of storage. After two months of storage, sprout length started to be shown in untreated (control). At the end of storage (5 months), the control treatment had the longest sprouts; however, sprout length was shorter in tuber treated with clove oil at $50 \mathrm{ppm}$ and $\mathrm{H}_{2} \mathrm{O}_{2}$ at $1 \%$. On the other hand, no sprouts were observed in CIPC and clove oil at 100 ppm and $\mathrm{H}_{2} \mathrm{O}_{2}$ at $2 \%$.

\section{Decay}

Data in Table (4) show that, there were significant increases in decay percentage with the prolongation of storage period. This finding may be due to the continuous chemical and biochemical changes in the tubers such as transformation of compounds to simple forms that more liable to fungal infection (Wills et al., 1981). These results are similar to those obtained by El-Sadr and Waterer (2005). However, all postharvest treatments were much better in reducing decay and thus longer storage periods. Potato tubers treated with CIPC, clove oil at $100 \mathrm{ppm}$ and $\mathrm{H}_{2} \mathrm{O}_{2}$ at $2 \%$ was the most effective treatments on reducing decay percentage during all storage_period, all of them no decay was observed in tubers till four months and gave low decay percentage at the end of storage ( 5 months). Similar results were obtained by Olsen et $\boldsymbol{a l . , ( 2 0 0 4 )}$ for CIPC and clove oil, Afek et al., (2000) and Kleinkopf et al., (2003)for $\mathrm{H}_{2} \mathrm{O}_{2}$. The decayed tubers started to be shown after 2 months of storage for untreated control and gave high percentage at the end of storage .clove oil at 50ppm and $\mathrm{H}_{2} \mathrm{O}_{2}$ at $1 \%$ was less effective in reducing the decay.

The reduction of decay by $\mathrm{H}_{2} \mathrm{O}_{2}$ treatment attributed to that $\mathrm{H}_{2} \mathrm{O}_{2}$ as reactive oxygen species (ROS) play important and manifold role in plant disease resistance to infection with pathogens. Bayomi , (2008) in postharvest application, Afek $\boldsymbol{e t}$ al.,(2000) and Ukuku. (2004) found that $\mathrm{H}_{2} \mathrm{O}_{2}$ treatment have been shown to decrease microbial load of potato tubers.

Frazier et al., (2004) found that significant reductions in disease severity rating and incidence when infected of potato tubers were treated with clove oil or $\mathrm{H}_{2} \mathrm{O}_{2}$.

Bong (2007) found that clove oil as essential oils enhanced phytotoxicity to sprouts and plant growth inhibiting activities and to posses' antiviral and antifungal activity exhibited fungicidal and antifungal activity for protecting the potato tubers against sprouting altering taste or quality of the treated commodity.

As for the interaction between postharvest and storage period, data in Table (4) reveal that potato tubers treated with clove oil at $100 \mathrm{ppm}$ and $\mathrm{H}_{2} \mathrm{O}_{2}$ at $2 \%$ gave the lowest percentage of decay at the end of storage period (5 months).

Table 4. Effect of sprout suppression on decay $\%$ of potato tubers during storage at $10{ }^{\circ} \mathrm{C}$.

\begin{tabular}{|c|c|c|c|c|c|c|c|}
\hline \multirow{3}{*}{ Treatments } & \multicolumn{6}{|c|}{ Storage periods(months) } & \multirow{3}{*}{ Mean } \\
\hline & 0 & 1 & 2 & 3 & 4 & 5 & \\
\hline & \multicolumn{6}{|c|}{$2011-2012$} & \\
\hline CIPC at 50 ppm & 0.00 & 0.00 & 0.00 & 0.00 & 0.00 & 5.67 & 0.95 \\
\hline Clove oil at $50 \mathrm{ppm}$ & 0.00 & 0.00 & 0.00 & 0.00 & 5.62 & 9.14 & 2.46 \\
\hline Clove oil at $100 \mathrm{ppm}$ & 0.00 & 0.00 & 0.00 & 0.00 & 0.00 & 0.00 & 0.00 \\
\hline $\mathrm{H}_{2} \mathrm{O}_{2}$ at $1 \%$ & 0.00 & 0.00 & 0.00 & 0.00 & 2.41 & 10.13 & 2.09 \\
\hline $\mathrm{H}_{2} \mathrm{O}_{2}$ at $2 \%$ & 0.00 & 0.00 & 0.00 & 0.00 & 0.00 & 4.26 & 0.71 \\
\hline Untreated (Control) & 0.00 & 0.00 & 2.75 & 14.23 & 28.13 & 42.82 & 14.66 \\
\hline Mean & 0.00 & 0.00 & 0.46 & 2.37 & 6.03 & 12.00 & 3.48 \\
\hline \multirow[t]{2}{*}{ L S D at $5 \%$} & $\mathrm{~T}$ & 0.16 & $\mathrm{~S}$ & 0.18 & $\mathrm{~T} * \mathrm{~S}$ & 0.22 & \\
\hline & \multicolumn{7}{|c|}{$2012-2013$} \\
\hline CIPC at $50 \mathrm{ppm}$ & 0.00 & 0.00 & 0.00 & 0.00 & 0.00 & 8.42 & 1.40 \\
\hline Clove oil at $50 \mathrm{ppm}$ & 0.00 & 0.00 & 0.00 & 0.00 & 10.13 & 17.82 & 4.66 \\
\hline Clove oil at $100 \mathrm{ppm}$ & 0.00 & 0.00 & 0.00 & 0.00 & 0.00 & 0.00 & 0.00 \\
\hline $\mathrm{H}_{2} \mathrm{O}_{2}$ at $1 \%$ & 0.00 & 0.00 & 0.00 & 0.00 & 0.00 & 16.13 & 2.69 \\
\hline $\mathrm{H}_{2} \mathrm{O}_{2}$ at $2 \%$ & 0.00 & 0.00 & 0.00 & 0.00 & 0.00 & 6.26 & 1.04 \\
\hline Untreated (Control) & 0.00 & 0.00 & 7.26 & 26.11 & 42.82 & 56.31 & 22.08 \\
\hline Mean & 0.00 & 0.00 & 1.21 & 4.35 & 8.83 & 17.49 & 5.31 \\
\hline L S D at $5 \%$ & $\mathrm{~T}$ & 0.11 & $\mathrm{~S}$ & 0.13 & $\mathrm{~T} * \mathrm{~S}$ & 0.17 & \\
\hline
\end{tabular}




\section{Dry matter content}

Data in Table (5) show that no changes in dry matter content of potato at the beginning of storage and then decreased with the prolongation of the storage period. Similar results were obtained by Ezzat et al., (2011). No changes in dry matter content in the first period of storage might be due to the tubers in this period were in dormancy period which decreased the enzyme activity of the tubers. However, the reduction in dry matter content during the last period of storage might be due to the higher rate of sugar loss through respiration (Wills et al., 1981).

Concerning the effect of postharvest treatments on dry matter content, data reveal that there were significant differences between treatments in dry matter content during storage in both seasons. However, potato tubers treated with clove oil at 100 ppm, CIPC and $\mathrm{H}_{2} \mathrm{O}_{2}$ at $2 \%$ were significantly higher in dry matter content then the other treatments. The lowest values were resulted in untreated control. Similar results were obtained by (Frazier et $\boldsymbol{a l} ., 2004$ ; Tullis and Grave 2006)who found that essential oil and / or their basic constituents slow down the activity of enzymatic reactions are, especially those related with tuber carbohydrate reserves are degraded to sugars and respiration as well as energy metabolism. The decrease in dry matter content in untreated control could be due to increasing the sprouts, weight loss and decay of tubers (TaperBomaolker et al., 2010).

The interaction between postharvest treatments and storage period was significant in the two seasons. After 5 months of storage, potato tubers treated with clove oil at $100 \mathrm{ppm}$ or $\mathrm{H}_{2} \mathrm{O}_{2}$ at $2 \%$ had the highest values of dry matter content.

Table 5. Effect of sprout suppression on dry matter \% of potato tubers during storage at $10 \quad{ }^{\circ} \mathrm{C}$.

\begin{tabular}{|c|c|c|c|c|c|c|c|}
\hline \multirow{3}{*}{ Treatments } & \multicolumn{6}{|c|}{ Storage periods(months) } & \multirow{3}{*}{ Mean } \\
\hline & 0 & 1 & 2 & 3 & 4 & 5 & \\
\hline & \multicolumn{6}{|c|}{$2011-2012$} & \\
\hline CIPC at 50 ppm & 24.29 & 24.23 & 23.82 & 23.40 & 22.68 & 22.14 & 23.43 \\
\hline Clove oil at $50 \mathrm{ppm}$ & 24.29 & 24.19 & 23.74 & 23.25 & 22.42 & 21.98 & 23.31 \\
\hline Clove oil at $100 \mathrm{ppm}$ & 24.29 & 24.24 & 23.91 & 23.84 & 22.89 & 22.58 & 23.63 \\
\hline $\mathrm{H}_{2} \mathrm{O}_{2}$ at $1 \%$ & 24.29 & 24.11 & 23.62 & 23.11 & 22.40 & 22.90 & 23.41 \\
\hline $\mathrm{H}_{2} \mathrm{O}_{2}$ at $2 \%$ & 24.29 & 24.20 & 23.81 & 23.52 & 22.70 & 22.47 & 23.49 \\
\hline Untreated (Control) & 24.29 & 24.09 & 23.41 & 23.02 & 22.32 & 21.44 & 23.09 \\
\hline Mean & 24.29 & 24.18 & 23.72 & 23.36 & 22.57 & 22.25 & 23.39 \\
\hline \multirow[t]{2}{*}{ L S D at $5 \%$} & $\mathrm{~T}$ & 0.10 & $\mathrm{~S}$ & 0.12 & $\mathrm{~T} * \mathrm{~S}$ & 0.14 & \\
\hline & \multicolumn{7}{|c|}{$2012-2013$} \\
\hline CIPC at 50 ppm & 23.17 & 23.10 & 22.82 & 22.35 & 21.92 & 21.46 & 22.47 \\
\hline Clove oil at $50 \mathrm{ppm}$ & 23.17 & 23.12 & 22.74 & 22.22 & 21.64 & 20.92 & 22.30 \\
\hline Clove oil at $100 \mathrm{ppm}$ & 23.17 & 23.07 & 22.95 & 22.74 & 22.22 & 21.82 & 22.66 \\
\hline $\mathrm{H}_{2} \mathrm{O}_{2}$ at $1 \%$ & 23.17 & 23.11 & 22.62 & 22.18 & 22.53 & 20.74 & 22.39 \\
\hline $\mathrm{H}_{2} \mathrm{O}_{2}$ at $2 \%$ & 23.17 & 23.14 & 22.84 & 22.54 & 22.10 & 21.70 & 22.58 \\
\hline Untreated (Control) & 23.17 & 23.02 & 22.30 & 21.90 & 21.31 & 20.20 & 21.98 \\
\hline Mean & 23.17 & 23.09 & 22.71 & 22.32 & 21.95 & 21.14 & 22.39 \\
\hline L S D at $5 \%$ & $\mathrm{~T}$ & 0.11 & $\mathrm{~S}$ & 0.14 & $\mathrm{~T} * \mathrm{~S}$ & 0.17 & \\
\hline
\end{tabular}

\section{Starch percentage}

Data in Table (6) show that there were significant difference between starch percentage and storage periods. The results clearly, indicate that starch content was decreased via prolonging the storage period, in the two seasons. This results were in agreement with those obtained by Awad et al.,(2007) and could be attributed to the hydrolysis of starch during storage period (Wills et al.,1980). Starch percentage as affected with sprout suppression is presented in Table (6). The results showed that all treatments were found affective on preventing starch degradation during storage as compared with untreated (control). The lowest values of starch content were in untreated (control) tubers. Moreover, in general, potato tubers treated with clove oil at 100 ppm, $\mathrm{H}_{2} \mathrm{O}_{2}$ at $2 \%$ and CIPC resulted in maintaining starch percentage. High content of starch could be due to the previous mentioned, reduce the sprouting and weight loss of tuber. Clove oil at $50 \mathrm{ppm}$ and $\mathrm{H}_{2} \mathrm{O}_{2}$ at $1 \%$ treatments had slight effects on starch preservation.

The interaction between postharvest treatments and storage period was significant in the two seasons. After 5 months of storage, potato tubers treated with clove oil at $100 \mathrm{ppm}$ followed by $\mathrm{H}_{2} \mathrm{O}_{2}$ at $2 \%$ had the highest starch values of starch percentage. The results were in agreement with those obtained by Olsen et al.(2004) for Clove oil and Kleinkoph et al. (2003) for $\mathrm{H}_{2} \mathrm{O}_{2}$. 
Table 6. Effect of sprout suppression on dry matter $\%$ of potato tubers during storage at $10 \quad{ }^{\circ} \mathrm{C}$.

\begin{tabular}{|c|c|c|c|c|c|c|c|}
\hline \multirow{3}{*}{ Treatments } & \multicolumn{6}{|c|}{ Storage periods(months) } & \multirow{3}{*}{ Mean } \\
\hline & 0 & 1 & 2 & 3 & 4 & 5 & \\
\hline & \multicolumn{6}{|c|}{$2011-2012$} & \\
\hline CIPC at $50 \mathrm{ppm}$ & 18.31 & 18.23 & 18.17 & 17.90 & 17.42 & 17.00 & 17.84 \\
\hline Clove oil at $50 \mathrm{ppm}$ & 18.31 & 18.18 & 18.80 & 17.72 & 17.07 & 16.41 & 17.75 \\
\hline Clove oil at $100 \mathrm{ppm}$ & 18.31 & 18.45 & 18.19 & 17.95 & 17.64 & 17.39 & 17.99 \\
\hline $\mathrm{H}_{2} \mathrm{O}_{2}$ at $1 \%$ & 18.31 & 18.16 & 18.10 & 17.61 & 17.00 & 16.32 & 17.58 \\
\hline $\mathrm{H}_{2} \mathrm{O}_{2}$ at $2 \%$ & 18.31 & 18.22 & 18.20 & 17.80 & 17.44 & 17.18 & 17.86 \\
\hline Untreated (Control) & 18.31 & 18.17 & 17.80 & 17.40 & 16.72 & 16.00 & 17.4 \\
\hline Mean & 18.31 & 18.24 & 18.21 & 17.73 & 17.22 & 16.72 & 17.74 \\
\hline \multirow[t]{2}{*}{ L S D at $5 \%$} & $\mathrm{~T}$ & 0.04 & $\mathrm{~S}$ & 0.11 & $\mathrm{~T} * \mathrm{~S}$ & 0.14 & \\
\hline & \multicolumn{7}{|c|}{$2012-2013$} \\
\hline CIPC at 50 ppm & 19.62 & 19.50 & 19.59 & 19.10 & 18.61 & 18.04 & 19.08 \\
\hline Clove oil at $50 \mathrm{ppm}$ & 19.62 & 19.52 & 19.22 & 18.70 & 17.91 & 17.41 & 18.73 \\
\hline Clove oil at $100 \mathrm{ppm}$ & 19.62 & 19.50 & 19.10 & 18.94 & 18.71 & 18.50 & 19.06 \\
\hline $\mathrm{H}_{2} \mathrm{O}_{2}$ at $1 \%$ & 19.62 & 19.45 & 19.11 & 18.62 & 17.74 & 17.30 & 18.64 \\
\hline $\mathrm{H}_{2} \mathrm{O}_{2}$ at $2 \%$ & 19.62 & 19.44 & 19.20 & 18.81 & 18.52 & 18.20 & 18.97 \\
\hline Untreated (Control) & 19.62 & 19.40 & 19.10 & 18.62 & 17.81 & 17.04 & 18.59 \\
\hline Mean & 19.62 & 19.47 & 19.22 & 18.79 & 18.22 & 17.75 & 18.85 \\
\hline L S D at $5 \%$ & $\mathrm{~T}$ & 0.06 & $\mathrm{~S}$ & 0.09 & $\mathrm{~T} * \mathrm{~S}$ & 0.11 & \\
\hline
\end{tabular}

\section{Conclusion}

The results suggest that potato tubers treated with Clove oil at $100 \mathrm{ppm}$ or $\mathrm{H}_{2} \mathrm{O}_{2}$ at $2 \%$ is a promising as natural alternative to CIPC for controlling sprouting and maintenance quality during storage at $10^{\circ} \mathrm{C}$ for 5 months.

\section{References}

Abd El-Moneium.M.R.A, H.S.El-Beltagi.,A.A.Aly. and A.E.Wl-Ansary. (2012). Antioxident enzyme activities and lipid peroxidation as biomarker for potato tuber stored by two essensial oils Caraway and Clove abd its main component carvone and eugenol. Asian Pacific Journal of Tropical Biomedicine. 5772-5780.

Afek.U. and S Warshavsky. (1998). Problems in storage of potatoes in Israel. In:Levey, D(ed). Potato in Hot Climate. Israel Agresearch Journal of the Agricultural Research Organization (in Hebrew, English abstracts)Agriculture Research Organization (ARO). The Volcani Center. Israel Vol. 9:97-114.

Afek.U., J. Orenstein and E. Nuriel. (2000). Using HPP(hydrogen peroxidase plus) to inhibit potato sprouting during storage. Am J Potato Res 77: (1) 63-65.

Anonymous,(2001). DECCO 271 Aerosol potato sprout inhibitor lable ELF Atochem North America. Monorivia, CA,USA.pp 1-2.

Awad.El-M.M.,Z.A.El-Sharkawy and M.S.Emam.(2007). Comparative effects of some postharvest treatments on sprout suppression of stored potato tubers and susceptibility for processing . J.Agric.Sci. Mansoura Univ.,32(11):9313- 9326.

Bayomi, Y.A. (2008).Improvement of postharvest keeping quality of white pepper fruits (Capsicum annum, L.) by hydrogen peroxidase treatment under storage conditions. Acta Biologica Szegdiensis 52 (1): 7-15.

Bong, U.(2007). Screening of natural plant volatiles to control the potato (solanum tuberosum) pathogens helminothosporium solani, fusarium solani, phoma faveata and rizoctonia solani. Potato Research 50 (2) :185-203.

Buitelaar .N. (1987). Sprout inhibition in ware potato storage.In:Rastovski,A and A.van Es(eds), storage of potatoes:post-harvest behavior, store design, storage practice, handling Pudoc, Wageningen, the Netherlands,pp. 331-341.

Burton.W.G.(1989). The potato $\left(3^{\text {th }}\right.$ ed.).Essex,UK:Longman Scientific \& Technical, $742 \mathrm{p}$.

CloveOilfor\&SilverScurfSupressioninstorage-06.pdf (accessed 26 January 2012).

Elsadr.H and D.Waterer. (2005). Efficacy of natural compounds to suppress sprouting and fusarium dry rot in potatoes.University of Saskatchewan, Department of Plant Sciences, 51 Campus Drive Sakatoon, Saskatchewan, Canada, S7N5A8.Available at

Es,A.V. and K.J.Hartmans. (1987b). Dormancy, sprouting and sprout inhibition.In:Rastovski,A and A.vanEs (Eds),storage of potatoes .postharvest Behavior, store desigen,storage practice, handling. Pudoc, wagening,the Netherlands,pp.114-132. 
Ezzat.A.S.,E.N.El-Banna. and A.A.El-Awady. (2011). Effect of spray with natural sprout inhibitors on productivity and storability of some new potato varities.Egypt.J.Hort.38,No 1,pp.2349.

Frazier

,M.G., G.E.Kleinkopf.,N.L.Olsen.,(2006).Clove oil for potato sprout and silver scurf suppression in storage. Presented at the Idaho Potato Conference on January 19.2012.

Frazier ,M.J, N.Olsen, and G.E.Kleinkopf.(2004). Organic and alternative methods for potato sprout control in storage. University of Idaho, College of Agriculture and life. Sciences,Idaho CIS 1120. Available at http://kimberly.uidaho.edu/potatoes/CIS1120.pdf.

http//www.cals.uidaho/Potatoes/Research\&Exten sion/Topic/Storage/

http://www.usask.ca/agriculture/plantsci/vegetabl epdf.

Kleinkopf ,G.E.,N.A.Oberg and N.Olsen(2003). Sprout inhibition in storage: current status, new chemistries and natural compound .Am J Potato Res 80 (5), 317- 327.

Nelson, N. (1974). A photometric adaptation of Somogyi methods for Determination of glucose. J. Biology Chem., 159: 375 - 380.

Okagami, N. and N.Tanno. (1992). Dormancy in Dioscorea:Gibberellic acid- induced prolongation of dormant state of subterranean organs. Plant Growth Regul., 25 (3): 215 - 222.

Olsen, N.,M.J.Fraizer and G.Kleinkoph.(2004).Potato sprout suppression from Clove oil. University of Idahoo Extension. www.Kimberly.Undaho.edu/Potatoes/Cloveoil80 6.pdf

Owolabi,M.S.,R.S.Olowu.,L.Lajide.,M.O.Oladime ji.,E.Padilla-Camberos.and J.M.FloresFernandez. (2013). Inhibition of potato tuber sprouting during storage by controlled release of essential oil using a wick application method.industrial crops and products. 45:83-87.

Pauly. G.,R.Douce. and J.P.Carde. (1981). Effect of B-pinene on spinah chloroplast.
Photosynthesis Z Pflanzenphydiol. 104 : 199 206.

Prang.R.,W.Kalt.,B.DaninielsLake.,C.Liew.,J.Walsh.,P.Dean.,R.Coffin and R.Page. (1997). Alternative to currently used potato sprout suppressants. Postharvest News and Information. 8(3): $37-41$.

Rastovski.A.(1987). Storage losses.In:Rastovski,A. Store Design , Storage Practice, Handling. Pudoc,Wageningen, The Netherland, pp.177-180.

Saravia. J.A.,and I.M.Rodrogues. (2011). Inhibition of potato tuber sprouting by pressure treatments .Int J Food Sci Technol. 46 (1):61-66.

Sharma,A.(2012).Essential oil as organic and alternative methods for potato (Solanumtuberosum L.)sprout control in storage. International J.of Eng. and Mathem. Sci. 1 Issue 1,pp.34-39.

Snedecor, G. W. and W. G. Cochran (1980).Statistical methods. Iowa State Univ. Press, USA.

Somogyi, M. (1952). Notes on sugar determination, Jour. Biology Chem., 195: 19-23.

Taper-

Bamnolker.P.,N.D.R.Fischer.,E.Blausov.,H.Ze mach.,O.Shoseyov. and D.Eshel. (2010). Mint essential oil induce or in hibit potato sprouting by differential alteration of apical meristem. Planta 232:179- 186 .

Tullis,B.M. and O.K. Grave.(2006). Brina Shrimp tolerance to potato sprout inhibitors. The Oklahama Junior Academy of Scince., Feb.21.

Ukuku. D.U.(2004). Effect of hydrogen peroxidase treatment on microbial quality and appearance of whole and fresh-cut melons contaminated with Salmonella spp.Int.J Food Micro.95: 137- 146.

Wills.R.H.H., T.H. Tee, D.Graham.,W.B.McGlasson. and E.G.Hall.(1981). Postharvest an introduction to physiology and handling in fruit and vegetables. The AVF Publishing Comp.Inc.Westport.Comn.

Yada.R.Y.,R.H.Coffin.,M.K.Keenan.,M.Fitts.,C.D ufault. and G.C.C.Tai.(1991). The effect of maleic hydrazide (potassium salt) on potato yield, sugar content and chip color of Kennebec and Norchip cultivars. Am Potato J 68:705-709. 


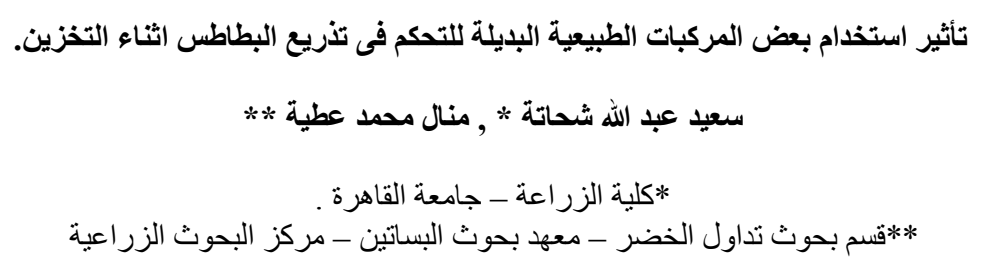

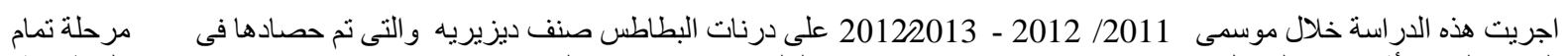

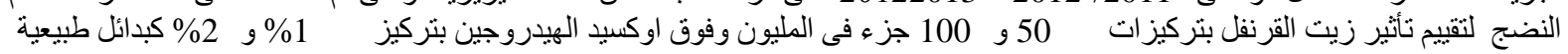

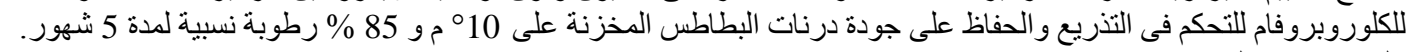

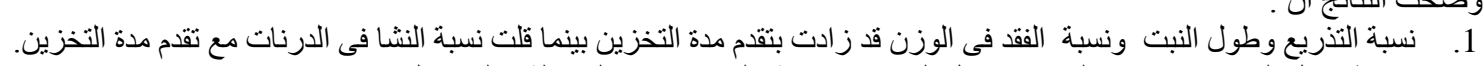
2.

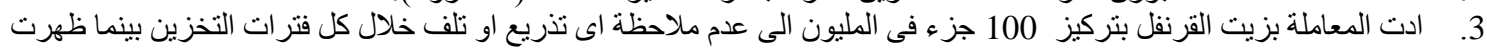

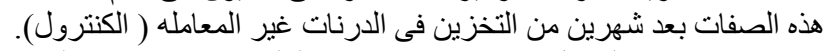

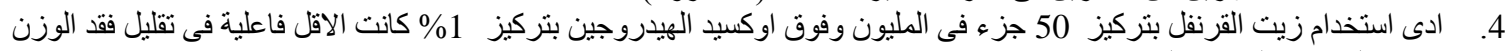

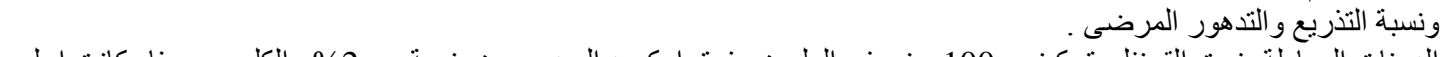

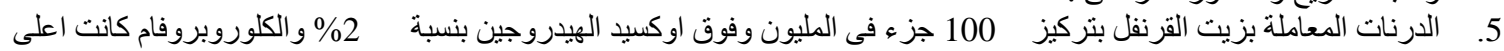

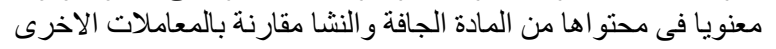

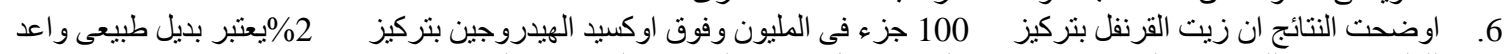

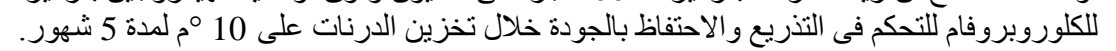

